\title{
Review Article \\ Contributions of Inflammatory Processes to the Development of the Early Stages of Diabetic Retinopathy
}

\begin{abstract}
Timothy S. Kern
Received 14 January 2007; Accepted 27 May 2007

Recommended by Subrata Chakrabarti

Diabetes causes metabolic and physiologic abnormalities in the retina, and these changes suggest a role for inflammation in the development of diabetic retinopathy. These changes include upregulation of iNOS, COX-2, ICAM-1, caspase 1, VEGF, and NF- $\kappa \mathrm{B}$, increased production of nitric oxide, prostaglandin E2, IL-1 $\beta$, and cytokines, as well as increased permeability and leukostasis. Using selective pharmacologic inhibitors or genetically modified animals, an increasing number of therapeutic approaches have been identified that significantly inhibit development of at least the early stages of diabetic retinopathy, especially occlusion and degeneration of retinal capillaries. A common feature of a number of these therapies is that they inhibit production of inflammatory mediators. The concept that localized inflammatory processes play a role in the development of diabetic retinopathy is relatively new, but evidence that supports the hypothesis is accumulating rapidly. This new hypothesis offers new insight into the pathogenesis of diabetic retinopathy, and offers novel targets to inhibit the ocular disease.
\end{abstract}

Copyright (C) 2007 Timothy S. Kern. This is an open access article distributed under the Creative Commons Attribution License, which permits unrestricted use, distribution, and reproduction in any medium, provided the original work is properly cited.

\section{INTRODUCTION}

Diabetic retinopathy classically has been regarded as a disease of the retinal microvasculature, and the natural history of the disease has been divided into an early, nonproliferative (or background) stage, and a later, proliferative stage. It is becoming appreciated also that cells of the neuroretina also are affected in diabetes. A number of metabolic or molecular abnormalities that are characteristic of inflammation have been detected in retinas of diabetic animals or patients, or in retinal cells exposed to elevated concentrations of glucose. In the following sections, we will review studies implicating inflammation in the pathogenesis of the early stages of diabetic retinopathy. This review will focus primarily on in vivo studies.

\section{HISTOPATHOLOGY OF EARLY STAGES OF DIABETIC RETINOPATHY}

Histologically, vascular lesions in the early stages of diabetic retinopathy in man and animals are characterized by the presence of saccular capillary microaneurysms, pericytedeficient capillaries, and obliterated and degenerate capillaries. These degenerate capillaries are not perfused, and so increases in their frequency represent reductions in retinal perfusion.
Capillary occlusion and degeneration initially occurs in single, isolated capillaries, and has no clinical importance when only few capillaries have become nonperfused. As more and more capillaries become occluded, however, retinal perfusion likely decreases, at least locally. Mechanisms believed to contribute to the degeneration of retinal capillaries in diabetes include (1) occlusion of the vascular lumen by white blood cells or platelets, (2) death of capillary cells secondary to biochemical abnormalities within the vascular cells themselves, or (3) capillary cell death secondary to products generated by other nearby cells (such as neurons or glia). All species studied to date have been found to show degeneration of retinal capillaries (Figure 1) as well as death of pericytes and endothelial cells, but microaneurysms are not commonly found in rodent models of diabetic retinopathy.

Diabetes also results in damage to nonvascular cells of the retina. Loss of ganglion cells has been detected in diabetic rats [1-13] and humans [4], but results are controversial in mice $[8,11,14,15]$. The neurodegeneration in diabetic rats has been detected as early as one month of diabetes [4], thus preceding (and possibly contributing to) the development of the vascular cell changes [4]. The possible role of neurodegeneration in diabetes-induced capillary degeneration has yet to be conclusively demonstrated, but a report that Nepafenac (a COX inhibitor) inhibited diabetes-induced degeneration of retinal capillaries while having no effect on the loss of retinal 


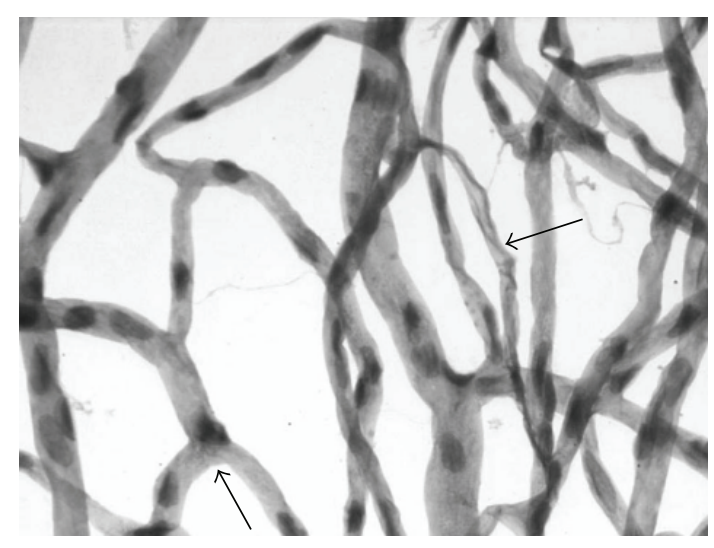

FIgURE 1: Capillary degeneration in a rat diabetic for 10 months. Large arrow: acellular (degenerate) capillary; small arrow: pericyte ghost.

ganglion cells suggests that the two degenerative events need not be causally linked (16).

Glia and other retinal cells also undergo changes in diabetes in some species. In diabetic rats and humans (but apparently not mice [8]), these cells changed from a quiescent to an injury-associated phenotype with high levels of expressed glial fibrillary acidic protein (GFAP) — a hallmark of glial cell activation $[3,5,8,14,16-20]$. Müller glial cells in diabetic rats showed evidence of cell death in some $[3,10]$, but not all [19], studies. Horizontal cells, amacrine cells, and photoreceptors also have been reported to undergo degeneration in diabetic rats $[7,9]$, but these changes are not known to be characteristics of retinal changes seen in diabetic patients so their significance remains to be learned. Diabetesinduced changes in retinal function [21-26] are consistent with diabetes causing metabolic alterations in the neural retina.

\section{INFLAMMATION}

Inflammation is a nonspecific response to injury that includes a variety of functional and molecular mediators, including recruitment and activation of leukocytes. Inflammation typically has beneficial effects on an acute basis, but can have undesirable effects if persisting chronically. The increased expression of many inflammatory proteins is regulated at the level of gene transcription through the activation of proinflammatory transcription factors, including NF- $\kappa \mathrm{B}$. These proinflammatory transcription factors are activated and play a critical role in amplifying and perpetuating the inflammatory process. Transcription factors associated with production of proinflammatory mediators include nuclear factor kappa B (NF- $\kappa \mathrm{B})$, activator protein 1 (AP-1), specificity protein $1(\mathrm{Sp} 1)$, peroxisome proliferator-activated receptors (PPARs) and other members of the nuclear receptor superfamily [27-30]. Proinflammatory proteins (including COX-2, interleukin-1, tumor necrosis factor alpha) can contribute to cell damage and death in tissues including brain and retina [31-34], at least in part via activation of NF- $\kappa \mathrm{B}$ [32].

\section{ROLE OF INFLAMMATION IN THE EARLY STAGES OF DIABETIC RETINOPATHY: ANIMAL STUDIES}

Many of the molecular and functional changes that are characteristics of inflammation (summarized below) have been detected in retinas from diabetic animals or humans, and in retinal cells cultured in elevated concentrations of glucose. Although many animal species have been studied as possible models of diabetic retinopathy, most of the studies linking inflammatory processes to the development of diabetic retinopathy have been conducted to date in rats and mice, and have focused on insulin-deficient models (type 1 diabetes).

\subsection{Leukostasis and platelet activation}

Attraction and adhesion of leukocytes to the vascular wall are important components of inflammatory processes. This leukostasis has been found to be significantly increased in retinas of diabetic animals [35-47], and might contribute to the capillary nonperfusion in diabetic retinopathy. Leukocyte stiffness has been reported to be increased in diabetes (decreased filterability) and to contribute to the development of capillary nonperfusion in retinal vessels [36, 48]. A second line of evidence shows that abnormal leukocyte adherence to retinal vessels in diabetes occurs via adhesion molecules. Diabetes increases expression of ICAM-1 in retinas of animals and humans $[38,49]$ and interaction of this adhesion molecule on retinal endothelia with the CD18 adhesion molecule on monocytes and neutrophils contributes to the diabetes-induced increase in leukostasis within retinal vessels [38]. Leukostasis has been postulated to be a factor in death of retinal endothelial cells in diabetes [40]. Using in situ perfusion methods, evidence consistent with capillary occlusion secondary to leukostasis has been observed in occasional retinal vessels (Figure 2), but it is unclear whether this occurred in vivo or was an artifact caused by the in vitro perfusion. Retinas from diabetic mice lacking ICAM-1 and CD18 are protected from the development of diabetesinduced increase in leukostasis, vascular permeability, and degeneration of retinal capillaries [46], showing these proteins to be important in the development of early stages of diabetic retinopathy. Whether their role in the development of the retinal disease results from capillary occlusion or some other mechanism, however, has not been explored.

A third postulated cause of capillary nonperfusion in diabetes involves platelets. Platelet microthrombi are present in the retinas of diabetic rats and humans, and have been spatially associated with apoptotic endothelial cells [50]. The selective antiplatelet drug (clopidogrel), however, did not prevent neuronal apoptosis, glial reactivity, capillary cell apoptosis, or acellular capillaries in retinas of diabetic rats (51), suggesting that platelets do not initiate the pathology of early diabetic retinopathy.

\subsection{Increased vascular permeability}

Breakdown of the blood-retinal barrier, another early event in the development of diabetic retinopathy, has been 


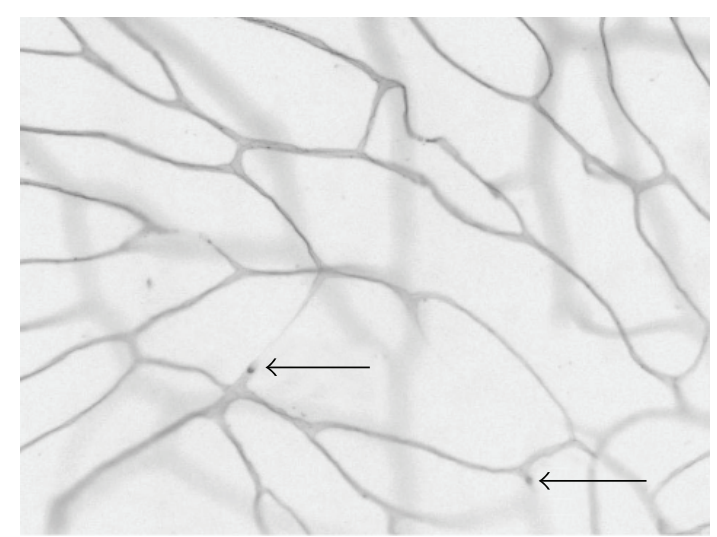

FIGURE 2: Adherence of white blood cells to the wall of retinal blood vessels (leukostasis). The vasculature of anesthetized animals was perfused with fluorescein-coupled concanavalin A lectin, resulting in stain of all vessel walls and more intense stain of the white blood cells. Occasionally, staining of a capillary was arrested where white blood cells were trapped in the vessel (arrow), suggesting that the blood cell might have occluded the vessel.

attributed to increases in leukostasis, cytokines, and growth factors [40, 51-54]. Increased permeability of the blood retinal barrier is known to occur in patients with diabetes, and this defect contributes to retinal edema and visual impairment in diabetic patients. Controversy remains as to how fast the permeability defect develops in retinas of diabetic animals, with reports ranging from 8 days to more than 6 months after onset of diabetes [41, 55-59]. There has been considerable effort directed towards developing means to assess increased vascular permeability within retinas of animal models, and to identify therapies to inhibit this defect. Therapies that have been found to inhibit the diabetes-induced increase in vascular permeability within the retina include aldose reductase inhibitors, protein kinase $\mathrm{C}$ inhibitors, tyrosine kinase inhibitors, aspirin, a COX-2 inhibitor, steroids, VEGF antagonist, TNF $\alpha$ receptor antagonists, and PPAR gamma ligands $[41,47,56,57,60-70]$.

\section{3. $3 N F-\kappa B$}

$\mathrm{NF}-\kappa \mathrm{B}$ is a widely expressed inducible transcription factor that is an important regulator of many genes involved in mammalian inflammatory and immune responses, proliferation and apoptosis. NF- $\kappa \mathrm{B}$ is composed of homodimers and heterodimers, the most abundant and best-studied form in mammalian cells consisting of the p65 and p50 subunits. Activation of NF- $\kappa \mathrm{B}$ typically involves the phosphorylation of cytoplasmic $\mathrm{I} \kappa \mathrm{B}$ by the $\mathrm{I} \kappa \mathrm{B}$ kinase (IKK) complex, resulting in $\mathrm{I} \kappa \mathrm{B}$ degradation via the proteosomal system. The degradation of $\mathrm{I} \kappa \mathrm{B}$ releases the NF- $\kappa \mathrm{B}$ heterodimers to translocate to the nucleus where they bind to nuclear DNA, leading to activation of specific subsets of genes. DNA-binding experiments (EMSA) have demonstrated NF- $\kappa \mathrm{B}$ to be activated in retinal endothelial cells or pericytes exposed to elevated glucose concentration and in retinas of diabetic rats $[71,72]$. Diabetes has been found to cause migration of the p65 sub- unit into the nucleus of retinal pericytes [73], and of the p50 subunit into nuclei of retinal endothelial cells, pericytes, ganglion cells, and cells of the inner nuclear layer [74].

Evidence in support of an important role of NF- $\kappa \mathrm{B}$ in the pathogenesis of early stages of diabetic retinopathy is twofold. First, inhibition of proteins whose expression is regulated by NF- $\kappa \mathrm{B}$ (such as iNOS and ICAM) inhibit diabetesinduced degeneration of retinal capillaries (described below). Second, compounds known to inhibit NF- $\kappa$ B likewise inhibit the development of the retinopathy. For example, several different antioxidants which inhibit the development of capillary degeneration and pericyte loss in retinas of diabetic rats [75] also inhibit the diabetes-induced activation of retinal NF- $\kappa \mathrm{B}(72)$. Likewise, low-intermediate doses of salicylates (aspirin, sodium salicylate, and sulfasalazine) which inhibited NF- $\kappa \mathrm{B}$ activation in retinas of diabetic rats, also inhibited expression of inflammatory mediators like iNOS and ICAM-1, and capillary degeneration and pericyte loss in those animals $(75 ; 77)$. Aspirin is known to inhibit also production of prostaglandins, but salicylate and sulfasalazine have much less of this activity, suggesting that the common action of these 3 salicylates to inhibit retinopathy in diabetes was not primarily mediated by inhibition of prostaglandins.

\subsection{4 iNOS}

iNOS expression is regulated at least in part by NF- $\kappa \mathrm{B}$. Interestingly, experimental sympathectomy itself increases gene and protein expression of iNOS in retinas of nondiabetic rats (78), suggesting that loss of sympathetic activity, such as which occurs in diabetes, might contribute to the upregulation of this inflammatory protein in the retina.

In retinas of diabetic animals, increased levels of nitric oxide products (nitrotyrosine, nitrite, nitrate) have been reported [76-78]. Upregulation of iNOS has been found in retinas of experimental diabetic rodents and patients in most studies [33, 55, 76, 78-82]. Diabetes-induced alterations in expression of other isoforms of nitric oxide synthase also have been reported $[83,84]$. A possible role of iNOS in the pathogenesis of diabetic retinopathy is suggested by the studies of aminoguanidine. Aminoguanidine is a relatively selective inhibitor of iNOS [85-88], and has been found to inhibit the diabetes-induced increase nitric oxide production and iNOS expression in retina [78].

Aminoguanidine also has been found to inhibit the development of the microvascular lesions of diabetic retinopathy in diabetic dogs [89], rats [90-92], and mice (Kern, unpublished data). Nevertheless, aminoguanidine also has other effects [93-100], so this therapy does not absolutely prove a role of iNOS in the pathogenesis of the retinopathy.

The role of iNOS in the development of the early stages of diabetic retinopathy recently has been investigated directly using mice genetically deficient in iNOS [101]. In that study, wildtype diabetic mice developed the expected degeneration of retinal capillaries, as well as increase in leukostasis and superoxide generation. In contrast, diabetic mice deficient in iNOS did not develop these structural or functional abnormalities. 
eNOS expression also has been reported to be elevated in the retinas in the diabetic rats, and it has been suggested that eNOS might play a role in the development of diabetesinduced leukostasis and/or retinopathy [41, 56, 83]. This possibility has not been experimentally addressed due, in part, to the hypertension that results in the absence of eNOS, as well as a lack of specific inhibitors of the enzyme.

\subsection{Cyclooxygenases}

COX-2 expression is regulated at least in part by NF- $\kappa$ B. In retinas of diabetic animals, induction of COX-2 as well as increased production of prostaglandins has been reported [33, 67, 102-104]. Ayalasomayajula and coworkers [104] have shown that $\mathrm{PGE}_{2}$ production by retinas from diabetic rats was significantly inhibited by celecoxib (a selective COX2 inhibitor), but not by a COX-1 inhibitor, suggesting that COX-2 is primarily responsible for the diabetes-induced increase in retinal production of $\mathrm{PGE}_{2}$ in diabetic rats. Inhibition of COX-2 has been reported to inhibit the diabetesinduced upregulation of retinal prostaglandins and VEGF [67], the increase in retinal vessel permeability and leukostasis [41], and the death of retinal endothelial cells cultured in diabetic-like concentrations of glucose [33]. The COX-2 inhibitor, Meloxicam, also reduced eNOS levels, inhibited NF$\kappa \mathrm{B}$ activation in the diabetic retina, and modestly, but significantly, reduced TNF $\alpha$ levels in the retina [41]. Its effect on histologic lesions of diabetic retinopathy was not studied.

Less selective COX inhibitors have inhibited the development of the retinopathy in diabetic dogs and rodents $[74,89]$, as well as the increase in vascular permeability in diabetic rodents [41]. Nepafenac is an inhibitor of cyclooxygenases that can be applied in eye drops. It was found to inhibit diabetesinduced prostaglandin production and leukocyte adhesion in retinal vessels of diabetic rats, and the diabetes-induced increase in the number of TUNEL-positive capillary cells, acellular capillaries, and pericyte ghosts in the retina [21].

\subsection{ICAM-1}

White blood cells bind to ICAM-1 on the surface of endothelial cells as a component of a multistep process leading to adherence of the white blood cell to the endothelial wall [38]. This leukostasis is known to be increased in retinal blood vessels in diabetes $[21,38,40-42,44,46,56,105,106]$, and this process is mediated via ICAM-1 [38]. ICAM-1 is upregulated by several stimuli, including VEGF, PARP activation, oxidative stress, and dylipidemia [72, 107-109], at least in part by $\mathrm{NF}-\kappa \mathrm{B}$.

Genetically modified C57B1/6J mice recently have been used to explore the roles of ICAM-1 and its ligand on white blood cells (CD18) in the pathogenesis of diabetes-induced retinal vascular disease [46]. Mice deficient in the genes for these proteins and their wildtype controls were made diabetic or experimentally galactosemic. After durations of up to 11 months (diabetes) or 22 months (galactosemia), wildtype diabetic or galactosemic animals developed capillary degeneration and pericyte loss as well as associated abnormalities including leukostasis, increased capillary permeability and capillary basement membrane thickening. In contrast, CD $18^{-/-}$and ICAM-1 $1^{-/-}$mice developed significantly fewer of each of these abnormalities, thus providing evidence that these inflammatory proteins play an important role in the pathogenesis of the retinopathy.

\subsection{VEGF}

VEGF is a proinflammatory molecule that plays a wellrecognized role in neovascularizaton and in increased permeability. VEGF expression is regulated largely by hypoxia, but it also accumulates in the retina early in diabetes, before any retinal hypoxia is yet apparent [110-112]. It is produced by multiple cell types in the retina in diabetes, including ganglion cells, Mueller cells, and pericytes. Repeated injections of high concentrations of VEGF in the eyes of nondiabetic monkeys result in retinal changes which in some ways resemble those in the early stages of diabetic retinopathy, including vascular tortuosity and microaneurysms $[113,114]$. Clinical trials using anti-VEGF therapies are showing promising results against advanced stages of diabetic retinopathy [115121].

\section{8. $8 I L-1 \beta$ and caspase- 1}

Levels of the proinflammatory cytokine, IL- $1 \beta$, are known to be increased in retinas from diabetic rats $[34,122,123]$. Intravitreal injection of IL- $1 \beta$ or exposure of retinal endothelial cells to the cytokine in vitro was shown to be capable of causing degeneration of retinal capillary endothelial cells [32], but the relevance of these findings to capillary degeneration in vivo is not clear because the levels of IL- $1 \beta$ likely were pharmacologically high. The role of IL- $1 \beta$ in the pathogenesis of diabetic retinopathy recently has been more directly studied using diabetic mice in whom the enzyme responsible for IL- $1 \beta$ production was inhibited or in whom the IL$1 \beta$ receptor was deleted. IL- $1 \beta$ is the predominant product of caspase- 1 , and the biological activity of IL- $1 \beta$ is mediated by binding to the cell surface receptor, IL-1R1. Activity of caspase- 1 is increased in retinas of diabetic mice, galactosefed mice, and diabetic humans, and in retinal Müller cells incubated in elevated glucose concentration [124]. Inhibition of caspase- 1 using minocycline inhibited the diabetesinduced increase in IL- $1 \beta$ and decreased degeneration of retinal capillaries in those animals [34]. Likewise, inhibition of IL- $1 \beta$ signaling using IL- $1 \beta$ receptor knock-out mice protected the animals from diabetes-induced retinal pathology at 7 months duration of diabetes [34]. The results indicate that activation of caspase- 1 and subsequent production of IL- $1 \beta$ play an important role in the development of diabetesinduced retinal pathology. One known action of IL- $1 \beta$ is to activate $\mathrm{NF}-\kappa \mathrm{B}$.

\subsection{TNF $\alpha$ and other cytokines}

Retinal levels of TNF $\alpha$ are significantly greater than normal in diabetic rats $[41,125]$. Eternacept is a soluble TNF $\alpha$ receptor that acts as competitive inhibitor to block effects of TNF $\alpha$ binding to cells. Eternacept reduced leukocyte adherence in 
retinal blood vessels of rats diabetic for 1 week compared to control [41]. Eternacept did not reduce retinal VEGF levels, but it inhibited blood-retinal barrier breakdown and NF- $\kappa \mathrm{B}$ activation in the diabetic retina. No effects of the therapy on histologic lesions of the retinopathy were evaluated in diabetic animals, but mice genetically deficient in TNF were reported in an abstract to be protected from galactose-induced retinopathy [126]. Epiretinal membranes obtained by vitrectomy, as well as cultured Muller glial cells stimulated with glycated albumin or high glucose, showed increased expression of monocyte chemotactic protein-1 mRNA and protein [127]. These studies suggested that monocyte chemotactic protein-1, under the regulation of $\mathrm{NF}-\kappa \mathrm{B}$, is a component of the diabetes-induced inflammation in the retina.

\subsection{Fas}

Fas levels are increased in retinas of diabetic rats $[41,126$, 128]. Blocking FasL in vivo has been shown to prevent endothelial cell damage, vascular leakage, and platelet accumulation in diabetes, suggesting that the Fas/FasL system might contribute to the diabetes-induced damage that contributes to the development of the retinopathy [128], but its role in the development of retinal histopathology has not been assessed.

\subsection{Complement}

Deposition of C5b-9, the terminal product of complement activation, has been observed within retinal blood vessels of diabetic rats and humans [129]. Endogenous inhibitors of complement activation, including CD55, CD59, and DAF, have been observed to have subnormal expression or impaired function as a result of nonenzymatic glycation [130132]. Whether or not inhibition of the complement system can inhibit the development of lesions characteristic of the retinopathy remains to be learned.

\subsection{Angiopoietin-1}

Angiopoietin-1 has been found to have anti-inflammatory actions, including inhibition of vascular permeability and adhesionprotein expression [133]. When administered intravitreally to diabetic rats, angiopoietin-1 normalized blood-retinalbarrier function, leukostasis and endothelial injury, and inhibited upregulation of retinal VEGF and ICAM1 mRNA and protein [56].

\section{SEVERAL THERAPIES THAT INHIBIT RETINOPATHY ARE KNOWN TO INHIBIT NF- $\kappa$ B}

\subsection{PARP}

Administration of a potent PARP inhibitor (PJ34) for nine months to diabetic rats significantly inhibited the diabetesinduced death of retinal microvascular cells and the development of early lesions of diabetic retinopathy, including capillary degeneration [72] (Figure 3). Evidence suggests that the inhibitor exerts this beneficial effect at least in part by regulating activation of the transcription factor, NF$\kappa \mathrm{B}$, and in particular, the $\mathrm{p} 50$ subunit of $\mathrm{NF}-\kappa \mathrm{B}$. In bovine retinal endothelial cells, PARP interacts directly with subunits of NF- $\kappa \mathrm{B}$, and inhibition of PARP activity blocked the hyperglycemia-induced increase in NF- $\kappa \mathrm{B}$ and proinflammatory gene products [72].

\subsection{Antioxidants}

Antioxidants have been found to inhibit the development of inflammatory changes in retinas of diabetic animals, including activation of NF- $\kappa \mathrm{B}$, leukostasis, and increased expression of iNOS [71, 134]. Consistent with this, antioxidants have been found to partially, but significantly, inhibit the development of acellular capillaries and pericyte ghosts in diabetic rats. Mixtures of $\alpha$-tocopherol and ascorbate [75], of $\alpha$-tocopherol, ascorbate, Trolox, acetylcysteine and selenium [75], $\alpha$-tocopherol alone (Kern, unpublished), and lipoic acid [135] have been found to significantly inhibit the development of acellular capillaries in retinas of diabetic rodents. The antioxidant and lipid-lowering agent, nicanartine, significantly inhibited diabetes-induced alterations in the number of retinal capillary endothelial cells and pericytes in rats, but had no effect on the formation of acellular capillaries [136].

\subsection{Benfotiamine}

Benfotiamine is a lipid-soluble thiamine derivative that is known to activate transketolase, and is believed to divert sugar metabolites away from glycolysis [137]. Benfotiamine significantly inhibited several hyperglycemia-induced abnormalities, including activation of NF- $\kappa$ B [137]. In addition, administration of benfotiamine significantly inhibited the development of acellular capillaries in retinas of diabetic rats [137]. Whether or not this beneficial effect of the drug on histopathology of the retina was secondary to regulation of $\mathrm{NF}-\kappa \mathrm{B}$ has not been investigated.

\subsection{Advanced glycation endproducts (AGEs) and their receptors}

Binding of AGEs or other related molecules to their extracellular receptors such as RAGE (receptor for advanced glycation endproducts) have a variety of intracellular effects, including activation of the proinflammatory NF- $\kappa \mathrm{B}$ and stimulation of leukostasis [138-143]. Pharmacological interventions interrupting RAGE-ligand interaction inhibit diabetesinduced degeneration of retinal capillaries in diabetes [25], but whether or not this is mediated by inhibition of NF- $\kappa \mathrm{B}$ has not been explored.

\subsection{Aldose reductase}

Inhibition of the polyol pathway enzyme aldose reductase has been reported to inhibit expression of ICAM-1, VCAM1, COX-2 expression and leukostasis via inhibition of NF$\kappa \mathrm{B}$ activity and nuclear translocation, and phosphorylation and degradation of $\mathrm{I} \kappa-\mathrm{B} \alpha$ [144-146]. The role of $\mathrm{NF}-\kappa \mathrm{B}$ 


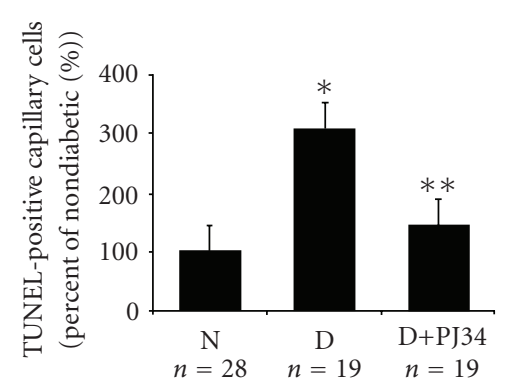

(a)

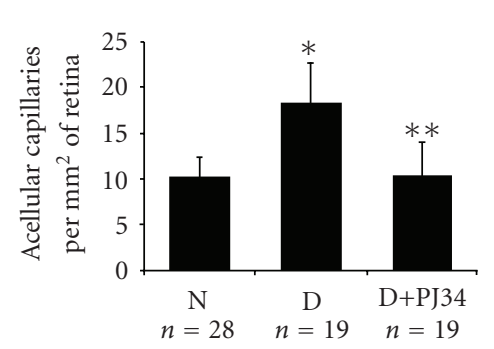

(b)

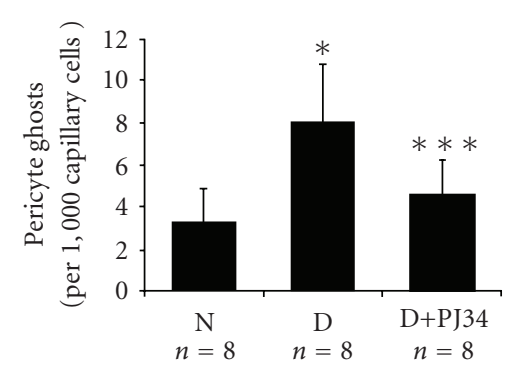

(c)

FIGURE 3: PARP inhibitor inhibits retinal capillary cell death and development of lesions of diabetic retinopathy ((a) TUNEL-positive cells, (b) acellular capillaries, and (c) pericyte ghosts). (N: nondiabetic rats; D: diabetic rats; D+PJ-34: diabetic rats treated with PJ-34. ${ }^{*} P<.005$ compared to nondiabetic control, ${ }^{* *} P<.0001$ compared to diabetic control, and ${ }^{* * *} P<.02$ compared to diabetic control.) Reprinted by permission from Diabetes Vol. 53; pp. 2960-2967; 2004(C)The American Diabetes Association.

regulation in reported effects of aldose reductase inhibitors on the development of retinopathy is unclear.

\subsection{Corticosteroids}

Corticosteroids are known to exert major anti-inflammatory effects. Intravitreal injection of such steroids has been found to inhibit diabetes-induced alterations in permeability of the retinal vasculature and retinal edema in patients [15133, 135-156].

\section{THERAPIES INHIBITING INFLAMMATION AND RETINOPATHY IN MULTIPLE WAYS}

\subsection{Minocycline}

Minocycline is a second-generation, chemically modified tetracycline [157] that exerts pleiotropic actions including anti-inflammatory effects distinct from its antimicrobial action $[158,159]$. Minocycline has neuroprotective qualities in models of cerebral ischemia, traumatic brain injuries, ALS, Huntington's, and Parkinson's disease in mice [160-169]. It has been speculated that its neuroprotective action is mediated by the inhibition of activation of caspase- 1 and caspase3 , inhibition of generation of IL- $1 \beta$, and iNOS $[170,171]$. Minocycline also inhibits activation of retinal microglia induced either by lipopolysaccharide or by diabetes, and prevents early caspase-3 activity and neuronal apoptosis in the retina of diabetic rats $[123,172]$. Long-term administration of minocycline also significantly inhibited the degeneration of retinal capillaries in diabetic mice and galactose-fed mice [34].

\subsection{Aspirin and salicylates}

Aspirin is known to inhibit production of prostaglandins as a result of cyclo-oxygenase inhibition. Sodium salicylate and sulphasalazine have less of this activity, however, but all of these salicylates were able to inhibit capillary degeneration in retinas of diabetic rats [74], suggesting that their common action to inhibit retinopathy was via inhibition of the NF- $\kappa \mathrm{B}$ pathway. Whether this occurs via direct or indirect actions remains to be learned.

\subsection{Aldose reductase inhibitors}

Aldose reductase inhibitors have long been studied for their ability to inhibit aldose reductase under hyperglycemic conditions. The ability of this class of drugs to inhibit diabetic retinopathy has been mixed in animals [8, 173, 174], and unsuccessful in diabetic patients $[175,176]$. Recently, aldose reductase inhibitors have been found to have potent anti-inflammatory actions, even in normoglycemia [144$146,177]$. The possibility that reported beneficial effects of aldose reductase inhibitors on diabetic retinopathy were due, instead, to anti-inflammatory actions has not yet been studied.

\section{ARE DIABETES-INDUCED INFLAMMATORY CHANGES IN THE RETINA INDEPENDENT OF EACH OTHER, OR ARE THEY INTERRELATED?}

Many of the inflammatory proteins shown above to be involved in the diabetes-induced degeneration of retinal capillaries are known to be regulated by NF- $\kappa \mathrm{B}$. It is conceivable that each of these proteins independently cause the capillary degeneration, but several pieces of evidence suggest that they act in a sequential, hierarchical pathway like that summarized in Figure 4. Evidence using retinal tissue from diabetic animals or incubated in high glucose indicates that (a) PARP regulates activity of $\mathrm{NF}-\kappa \mathrm{B}$ as well as expression of ICAM1 [72], (b) inhibition of $\mathrm{NF}-\kappa \mathrm{B}$ with sulfasalazine inhibits expression of iNOS, ICAM-1, VCAM, COX-2 [74, 148], (c) inhibition of iNOS inhibits the hyperglycemia-induced generation of prostaglandin [33], whereas the opposite reaction (regulation of nitric oxide production by COX-2) was not detected, and (d) inhibition of COX inhibits expression of ICAM-1 and leukostasis [21]. This pathway undoubtedly will become more complicated and interactive as more information becomes available about the role of proinflammatory proteins and transcription factors in the development of diabetic retinopathy. Many cytokines are known to activate NF$\kappa \mathrm{B}$ and other proinflammatory mediators, thus, even now 


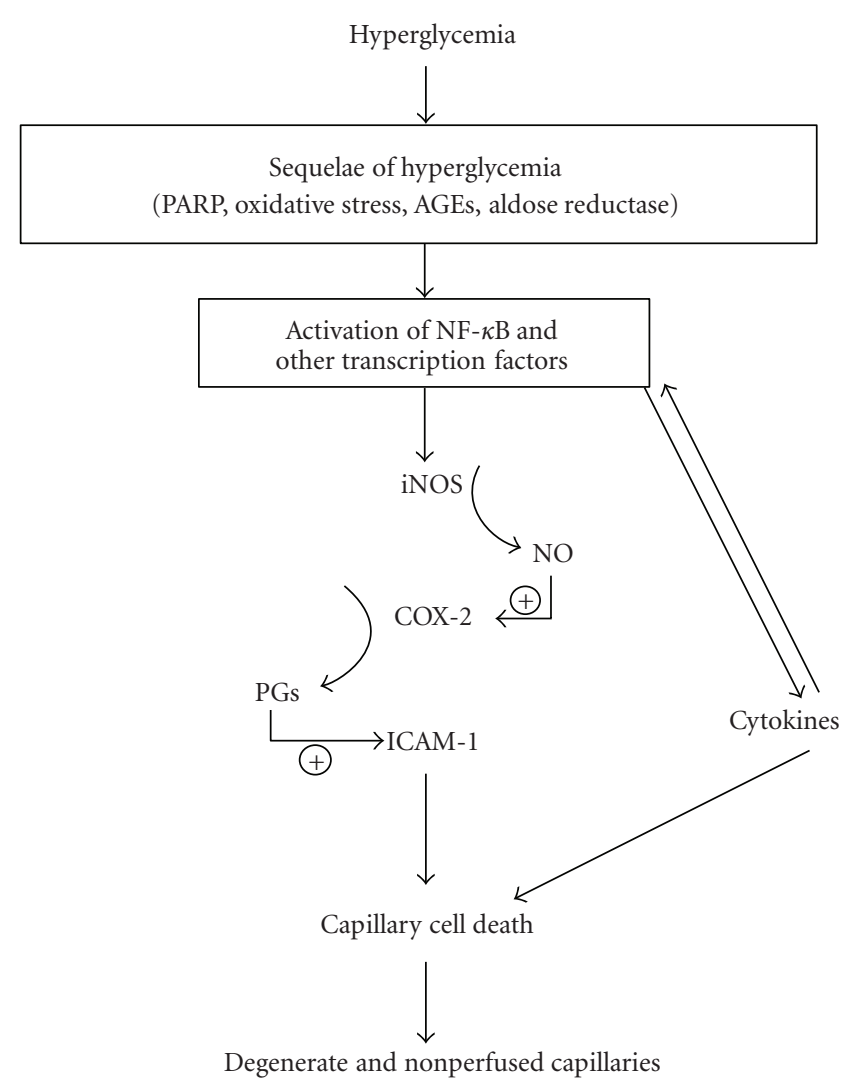

FIGURE 4: Working hypothesis of the contribution of inflammatory processes in the pathogenesis of capillary degeneration and other lesions of early diabetic retinopathy. The capillary degeneration can be inhibited in diabetic animals at any of several different points along this pathway.

suggesting considerable complexity in the initiation and regulation of this pro-inflammatory "pathway."

\section{IS NF- $\kappa$ B THE ONLY REGULATOR OF INFLAMMATORY GENE TRANSCRIPTION IN DIABETIC RETINOPATHY?}

Multiple transcription factors have been shown to regulate inflammation, so it seems unlikely that NF- $\kappa$ B is the only regulator of diabetes-induced inflammation in diabetic retinopathy. Retinas from diabetic rats have been reported to have increased expression of another transcription factor, CCAAT/enhancer-binding protein-beta [147], but this was not confirmed [148]. HIF- $1 \alpha$ expression in retinas of diabetic NOD mice increased with duration of diabetes, increased immunostaining for HIF- $1 \alpha$ being demonstrated in the inner (but not outer) retina [178]. To date, other transcription factors involved in regulation of inflammation seem not to have been studied in vivo in relation to diabetic retinopathy.

\section{INFLAMMATION IN HUMAN DIABETIC RETINOPATHY}

Evidence that inflammatory processes play an important role in the degeneration of retinal capillaries in diabetic patients is less complete than that in animals, but is in many ways consistent with the animal studies. Increases in levels of TNF $\alpha$, IL $-1 \beta$, and other inflammatory mediators have been shown in vitreous of diabetic patients [179-184]. Activity of caspase-1, the enzyme responsible for production of IL- $1 \beta$, is increased in retinas of diabetic humans, and correlates with the distribution of lesions in the retina [185]. Deposition of C5b-9, the terminal product of complement activation, has been observed within retinal blood vessels of diabetic humans [129].

Prospective clinical trials to assess the possible effect of aspirin on diabetic retinopathy in patients have yielded contradictory results. Aspirin treatment resulted in a statistically significant (although weak) inhibition of the mean yearly increase in the number of microaneurysms in the DAMAD trial [186], whereas no beneficial effect was observed on any aspect of retinopathy in the ETDRS trial [187]. The lack of effect of aspirin in the ETDRS is likely attributable, in part, to the greater severity of retinopathy at the onset than in the DAMAD trial or animal studies, and the lower doses of aspirin used. In light of the different conclusions reached in these clinical trials, and positive results achieved in animal studies, it seems prudent to reserve judgement at this time about whether or not aspirin might inhibit diabetic retinopathy in humans.

\section{CONCLUSIONS}

In composite, numerous defects that develop in retinas as a result of diabetes are consistent with a diabetes-induced inflammatory response in that tissue. These inflammatory changes apparently are important in the pathogenesis of diabetic retinopathy, since inhibition of this inflammatory cascade at any of multiple steps can inhibit the early stages of diabetic retinopathy (notably, degeneration of retinal capillaries) in animals. Findings of diabetes-induced inflammatory changes, generally, in the human eye also, are consistent with the postulate that inflammatory processes contribute to the development of diabetic retinopathy. The evidence in diabetic animals is sufficient to warrant further investigations of the role of inflammation in the development of diabetic retinopathy in patients.

\section{ACKNOWLEDGMENTS}

This work was funded by PHS Grants EY00300, DK57733, the Medical Research Service of the Department of Veteran Affairs, and the Kristin C. Dietrich Diabetes Research Award.

\section{ABBREVIATIONS}

iNOS: Inducible isoform of nitric oxide synthase

COX: Cyclooxygenase

ICAM: Intercellular adhesion molecule

VEGF: Vascular endothelial growth factor

NF- $\kappa$ B: Nuclear factor kappa beta

IL-1 $\beta$ : Interleukin 1beta 
TNF $\alpha$ : Tumor necrosis factor alpha

EMSA: Electromobility shift assay

eNOS: Endothelial isoform of nitric oxide synthase

PARP: Poly(ADP-ribose) polymerase

\section{REFERENCES}

[1] A. A. Sima, W.-X. Zhang, P. V. Cherian, and S. Chakrabarti, "Impaired visual evoked potential and primary axonopathy of the optic nerve in the diabetic BB/W-rat," Diabetologia, vol. 35, no. 7, pp. 602-607, 1992.

[2] M. Kamijo, P. V. Cherian, and A. A. F. Sima, "The preventive effect of aldose reductase inhibition on diabetic optic neuropathy in the BB/W-rat," Diabetologia, vol. 36, no. 10, pp. 893-898, 1993.

[3] H. P. Hammes, H. J. Federoff, and M. Brownlee, "Nerve growth factor prevents both neuroretinal programmed cell death and capillary pathology in experimental diabetes," Molecular Medicine, vol. 1, no. 5, pp. 527-534, 1995.

[4] A. J. Barber, E. Lieth, S. A. Khin, D. A. Antonetti, A. G. Buchanan, and T. W. Gardner, "Neural apoptosis in the retina during experimental and human diabetes: early onset and effect of insulin," Journal of Clinical Investigation, vol. 102, no. 4, pp. 783-791, 1998.

[5] X.-X. Zeng, Y.-K. Ng, and E.-A. Ling, "Neuronal and microglial response in the retina of streptozotocin-induced diabetic rats," Visual Neuroscience, vol. 17, no. 3, pp. 463-471, 2000.

[6] E. Lieth, T. W. Gardner, A. J. Barber, and D. A. Antonetti, "Retinal neurodegeneration: early pathology in diabetes," Clinical and Experimental Ophthalmology, vol. 28, no. 1, pp. 3-8, 2000.

[7] Y. Aizu, K. Oyanagi, J. Hu, and H. Nakagawa, "Degeneration of retinal neuronal processes and pigment epithelium in the early stage of the streptozotocin-diabetic rats," Neuropathology, vol. 22, no. 3, pp. 161-170, 2002.

[8] V. Asnaghi, C. Gerhardinger, T. Hoehn, A. Adeboje, and M. Lorenzi, "A role for the polyol pathway in the early neuroretinal apoptosis and glial changes induced by diabetes in the rat," Diabetes, vol. 52, no. 2, pp. 506-511, 2003.

[9] S.-H. Park, J.-W. Park, S.-J. Park, et al., "Apoptotic death of photoreceptors in the streptozotocin-induced diabetic rat retina," Diabetologia, vol. 46, no. 9, pp. 1260-1268, 2003.

[10] L. L. Kusner, V. P. Sarthy, and S. Mohr, "Nuclear translocation of glyceraldehyde-3-phosphate dehydrogenase: a role in high glucose-induced apoptosis in retinal Müller cells," Investigative Ophthalmology \& Visual Science, vol. 45, no. 5, pp. 1553-1561, 2004.

[11] P. M. Martin, P. Roon, T. K. Van Ells, V. Ganapathy, and S. B. Smith, "Death of retinal neurons in streptozotocin-induced diabetic mice," Investigative Ophthalmology \& Visual Science, vol. 45, no. 9, pp. 3330-3336, 2004.

[12] X. Ning, Q. Baoyu, L. Yuzhen, S. Shuli, E. Reed, and Q. Q. Li, "Neuro-optic cell apoptosis and microangiopathy in KKAY mouse retina," International Journal of Molecular Medicine, vol. 13, no. 1, pp. 87-92, 2004.

[13] M. Seki, T. Tanaka, H. Nawa, et al., "Involvement of brainderived neurotrophic factor in early retinal neuropathy of streptozotocin-induced diabetes in rats: therapeutic potential of brain-derived neurotrophic factor for dopaminergic amacrine cells," Diabetes, vol. 53, no. 9, pp. 2412-2419, 2004.
[14] R. A. Feit-Leichman, R. Kinouchi, M. Takeda, et al., "Vascular damage in a mouse model of diabetic retinopathy: relation to neuronal and glial changes," Investigative Ophthalmology \& Visual Science, vol. 46, no. 11, pp. 4281-4287, 2005.

[15] D. Gaucher, J.-A. Chiappore, M. Pâques, et al., "Microglial changes occur without neural cell death in diabetic retinopathy," Vision Research, vol. 47, no. 5, pp. 612-623, 2007.

[16] E. Lieth, A. J. Barber, B. Xu, et al., "Glial reactivity and impaired glutamate metabolism in short-term experimental diabetic retinopathy," Diabetes, vol. 47 , no. 5, pp. 815-820, 1998.

[17] M. Mizutani, C. Gerhardinger, and M. Lorenzi, "Müller cell changes in human diabetic retinopathy," Diabetes, vol. 47, no. 3, pp. 445-449, 1998.

[18] A. J. Barber, D. A. Antonetti, T. W. Gardner, et al., "Altered expression of retinal occludin and glial fibrillary acidic protein in experimental diabetes," Investigative Ophthalmology \& Visual Science, vol. 41, no. 11, pp. 3561-3568, 2000.

[19] E. Rungger-Brändle, A. A. Dosso, and P. M. Leuenberger, "Glial reactivity, an early feature of diabetic retinopathy," Investigative Ophthalmology \& Visual Science, vol. 41, no. 7, pp. 1971-1980, 2000.

[20] E. Agardh, A. Bruun, and C.-D. Agardh, "Retinal glial cell immunoreactivity and neuronal cell changes in rats with STZinduced diabetes," Current Eye Research, vol. 23, no. 4, pp. 276-284, 2001.

[21] T. S. Kern, C. M. Miller, Y. Du, et al., “Topical administration of nepafenac inhibits diabetes-induced retinal microvascular disease and underlying abnormalities of retinal metabolism and physiology," Diabetes, vol. 56, no. 2, pp. 373-379, 2007.

[22] Y. Shirao and K. Kawasaki, "Electrical responses from diabetic retina," Progress in Retinal and Eye Research, vol. 17, no. 1, pp. 59-76, 1998.

[23] Q. Li, E. Zemel, B. Miller, and I. Perlman, "Early retinal damage in experimental diabetes: electroretinographical and morphological observations," Experimental Eye Research, vol. 74, no. 5, pp. 615-625, 2002.

[24] H. A. Hancock and T. W. Kraft, "Oscillatory potential analysis and ERGs of normal and diabetic rats," Investigative Ophthalmology \& Visual Science, vol. 45, no. 3, pp. 1002-1008, 2004.

[25] G. R. Barile, S. I. Pachydaki, S. R. Tari, et al., "The RAGE axis in early diabetic retinopathy," Investigative Ophthalmology \& Visual Science, vol. 46, no. 8, pp. 2916-2924, 2005.

[26] J. A. Phipps, P. Yee, E. L. Fletcher, and A. J. Vingrys, "Rod photoreceptor dysfunction in diabetes: activation, deactivation, and dark adaptation," Investigative Ophthalmology \& Visual Science, vol. 47, no. 7, pp. 3187-3194, 2006.

[27] P. G. Winyard and D. R. Blake, "Antioxidants, redoxregulated transcription factors, and inflammation," Advances in Pharmacology, vol. 38, pp. 403-421, 1997.

[28] D. Jourd'heuil, Z. Morise, E. M. Conner, and M. B. Grisham, "Oxidants, transcription factors, and intestinal inflammation,” Journal of Clinical Gastroenterology, vol. 25, supplement 1, pp. S61-S72, 1997.

[29] I. Rahman, "Oxidative stress, transcription factors and chromatin remodelling in lung inflammation," Biochemical Pharmacology, vol. 64, no. 5-6, pp. 935-942, 2002.

[30] L. Escoubet-Lozach, C. K. Glass, and S. I. Wasserman, "The role of transcription factors in allergic inflammation," Journal of Allergy and Clinical Immunology, vol. 110, no. 4, pp. 553-564, 2002. 
[31] V. J. Quagliarello, B. Wispelwey, W. J. Long Jr., and W. M. Scheld, "Recombinant human interleukin-1 induces meningitis and blood-brain barrier injury in the rat: characterization and comparison with tumor necrosis factor," Journal of Clinical Investigation, vol. 87, no. 4, pp. 1360-1366, 1991.

[32] R. A. Kowluru and S. Odenbach, "Role of interleukin- $1 \beta$ in the pathogenesis of diabetic retinopathy," British Journal of Ophthalmology, vol. 88, no. 10, pp. 1343-1347, 2004.

[33] Y. Du, V. P. Sarthy, and T. S. Kern, "Interaction between NO and COX pathways in retinal cells exposed to elevated glucose and retina of diabetic rats," American Journal of Physiology, vol. 287, pp. R735-R741, 2004.

[34] J. A. Vincent and S. Mohr, "Inhibition of caspase$1 /$ interleukin- $1 \beta$ signaling prevents degeneration of retinal capillaries in diabetes and galactosemia," Diabetes, vol. 56, no. 1, pp. 224-230, 2007.

[35] S. Schroder, W. Palinski, and G. W. Schmid-Schonbein, "Activated monocytes and granulocytes, capillary nonperfusion, and neovascularization in diabetic retinopathy," American Journal of Pathology, vol. 139, no. 1, pp. 81-100, 1991.

[36] A. G. Harris, T. C. Skalak, and D. L. Hatchell, "Leukocytecapillary plugging and network resistance are increased in skeletal muscle of rats with streptozotocin-induced hyperglycemia," International Journal of Microcirculation, Clinical and Experimental, vol. 14, no. 3, pp. 159-166, 1994.

[37] D. L. Hatchell, C. A. Wilson, and P. Saloupis, "Neutrophils plug capillaries in acute experimental retinal ischemia," Microvascular Research, vol. 47, no. 3, pp. 344-354, 1994.

[38] K. Miyamoto, S. Khosrof, S.-E. Bursell, et al., "Prevention of leukostasis and vascular leakage in streptozotocin-induced diabetic retinopathy via intercellular adhesion molecule- 1 inhibition," Proceedings of the National Academy of Sciences of the United States of America, vol. 96, no. 19, pp. 10836-10841, 1999.

[39] A. Nonaka, J. Kiryu, A. Tsujikawa, et al., "PKC- $\beta$ inhibitor (LY333531) attenuates leukocyte entrapment in retinal microcirculation of diabetic rats," Investigative Ophthalmology \& Visual Science, vol. 41, no. 9, pp. 2702-2706, 2000.

[40] A. M. Joussen, T. Murata, A. Tsujikawa, B. Kirchhof, S.-E. Bursell, and A. P. Adamis, "Leukocyte-mediated endothelial cell injury and death in the diabetic retina," American Journal of Pathology, vol. 158, no. 1, pp. 147-152, 2001.

[41] A. M. Joussen, V. Poulaki, N. Mitsiades, et al., "Nonsteroidal anti-inflammatory drugs prevent early diabetic retinopathy via TNF- $\alpha$ suppression," The FASEB Journal, vol. 16, no. 3, pp. 438-440, 2002.

[42] N. Kinoshita, A. Kakehashi, S. Inoda, et al., "Effective and selective prevention of retinal leukostasis in streptozotocininduced diabetic rats using gliclazide," Diabetologia, vol. 45, no. 5, pp. 735-739, 2002.

[43] F. Mori, T. Hikichi, T. Nagaoka, J. Takahashi, N. Kitaya, and A. Yoshida, "Inhibitory effect of losartan, an AT1 angiotensin II receptor antagonist, on increased leucocyte entrapment in retinal microcirculation of diabetic rats," British Journal of Ophthalmology, vol. 86, no. 10, pp. 1172-1174, 2002.

[44] T. C. Moore, J. E. Moore, Y. Kaji, et al., "The role of advanced glycation end products in retinal microvascular leukostasis," Investigative Ophthalmology \& Visual Science, vol. 44, no. 10, pp. 4457-4464, 2003.

[45] R. Tadayoni, M. Paques, A. Gaudric, and E. Vicaut, "Erythrocyte and leukocyte dynamics in the retinal capillaries of diabetic mice," Experimental Eye Research, vol. 77, no. 4, pp. 497-504, 2003.
[46] A. M. Joussen, V. Poulaki, M. L. Le, et al., "A central role for inflammation in the pathogenesis of diabetic retinopathy," The FASEB Journal, vol. 18, no. 12, pp. 1450-1452, 2004.

[47] H. Tamura, K. Miyamoto, J. Kiryu, et al., "Intravitreal injection of corticosteroid attenuates leukostasis and vascular leakage in experimental diabetic retina," Investigative Ophthalmology \& Visual Science, vol. 46, no. 4, pp. 1440-1444, 2005.

[48] L. W. Kelly, C. A. Barden, J. S. Tiedeman, and D. L. Hatchell, "Alterations in viscosity and filterability of whole blood and blood cell subpopulations in diabetic cats," Experimental Eye Research, vol. 56, no. 3, pp. 341-347, 1993.

[49] D. J. Lefer, D. S. McLeod, C. Merges, and G. A. Lutty, "Immunolocalization of ICAM-1 (CD54) in the posterior eye of sickle cell and diabetic patients," Investigative Ophthalmology \& Visual Science, vol. 34, p. 1206, 1993.

[50] D. Boeri, M. Maiello, and M. Lorenzi, "Increased prevalence of microthromboses in retinal capillaries of diabetic individuals," Diabetes, vol. 50, no. 6, pp. 1432-1439, 2001.

[51] D. A. Antonetti, A. J. Barber, S. Khin, et al., "Vascular permeability in experimental diabetes is associated with reduced endothelial occludin content: vascular endothelial growth factor decreases occludin in retinal endothelial cells," Diabetes, vol. 47, no. 12, pp. 1953-1959, 1998.

[52] D. A. Antonetti, E. Lieth, A. J. Barber, and T. W. Gardner, "Molecular mechanisms of vascular permeability in diabetic retinopathy," Seminars in Ophthalmology, vol. 14, no. 4, pp. 240-248, 1999.

[53] J. L. Wilkinson-Berka, "Vasoactive factors and diabetic retinopathy: vascular endothelial growth factor, cycoloxygenase-2 and nitric oxide," Current Pharmaceutical Design, vol. 10, no. 27, pp. 3331-3348, 2004.

[54] N. S. Harhaj, E. A. Felinski, E. B. Wolpert, J. M. Sundstrom, T. W. Gardner, and D. A. Antonetti, "VEGF activation of protein kinase $\mathrm{C}$ stimulates occludin phosphorylation and contributes to endothelial permeability," Investigative Ophthalmology \& Visual Science, vol. 47, no. 11, pp. 5106-5115, 2006.

[55] A. Carmo, J. G. Cunha-Vaz, A. P. Carvalho, and M. C. Lopes, "Nitric oxide synthase activity in retinas from noninsulin-dependent diabetic Goto-Kakizaki rats: correlation with blood-retinal barrier permeability," Nitric Oxide, vol. 4, no. 6, pp. 590-596, 2000.

[56] A. M. Joussen, V. Poulaki, A. Tsujikawa, et al., "Suppression of diabetic retinopathy with angiopoietin-1," American Journal of Pathology, vol. 160, no. 5, pp. 1683-1693, 2002.

[57] A. B. El-Remessy, M. A. Behzadian, G. Abou-Mohamed, T. Franklin, R. W. Caldwell, and R. B. Caldwell, "Experimental diabetes causes breakdown of the blood-retina barrier by a mechanism involving tyrosine nitration and increases in expression of vascular endothelial growth factor and urokinase plasminogen activator receptor," American Journal of Pathology, vol. 162, no. 6, pp. 1995-2004, 2003.

[58] X. Xu, Q. Zhu, X. Xia, S. Zhang, Q. Gu, and D. Luo, "Blood-retinal barrier breakdown induced by activation of protein kinase $\mathrm{C}$ via vascular endothelial growth factor in streptozotocin-induced diabetic rats," Current Eye Research, vol. 28, no. 4, pp. 251-256, 2004.

[59] B. A. Berkowitz, R. Roberts, H. Luan, J. Peysakhov, X. Mao, and K. A. Thomas, "Dynamic contrast-enhanced MRI measurements of passive permeability through blood retinal barrier in diabetic rats," Investigative Ophthalmology \& Visual Science, vol. 45, no. 7, pp. 2391-2398, 2004. 
[60] R. G. Tilton, K. Chang, G. Pugliese, et al., "Prevention of hemodynamic and vascular albumin filtration changes in diabetic rats by aldose reductase inhibitors," Diabetes, vol. 38, no. 10, pp. 1258-1270, 1989.

[61] L. P. Aiello, S.-E. Bursell, A. Clermont, et al., "Vascular endothelial growth factor-induced retinal permeability is mediated by protein kinase $\mathrm{C}$ in vivo and suppressed by an orally effective $\beta$-isoform-selective inhibitor," Diabetes, vol. 46, no. 9, pp. 1473-1480, 1997.

[62] R. G. Tilton, K. C. Chang, W. S. Lejeune, C. C. Stephan, T. A. Brock, and J. R. Williamson, "Role for nitric oxide in the hyperpermeability and hemodynamic changes induced by intravenous VEGF," Investigative Ophthalmology \& Visual Science, vol. 40, no. 3, pp. 689-696, 1999.

[63] K. Miyamoto, S. Khosrof, S.-E. Bursell, et al., "Vascular endothelial growth factor (VEGF)-induced retinal vascular permeability is mediated by intercellular adhesion molecule-1 (ICAM-1)," American Journal of Pathology, vol. 156, no. 5, pp. 1733-1739, 2000.

[64] M. Nakajima, M. J. Cooney, A. H. Tu, et al., "Normalization of retinal vascular permeability in experimental diabetes with genistein," Investigative Ophthalmology \& Visual Science, vol. 42, no. 9, pp. 2110-2114, 2001.

[65] M. Takeda, F. Mori, A. Yoshida, et al., "Constitutive nitric oxide synthase is associated with retinal vascular permeability in early diabetic rats," Diabetologia, vol. 44, no. 8, pp. 10431050, 2001.

[66] D. A. Antonetti, E. B. Wolpert, L. DeMaio, N. S. Harhaj, and R. C. Scaduto Jr., "Hydrocortisone decreases retinal endothelial cell water and solute flux coincident with increased content and decreased phosphorylation of occludin," Journal of Neurochemistry, vol. 80, no. 4, pp. 667-677, 2002.

[67] S. P. Ayalasomayajula and U. B. Kompella, "Celecoxib, a selective cyclooxygenase- 2 inhibitor, inhibits retinal vascular endothelial growth factor expression and vascular leakage in a streptozotocin-induced diabetic rat model," European Journal of Pharmacology, vol. 458, no. 3, pp. 283-289, 2003.

[68] M. Cukiernik, D. Hileeto, T. Evans, S. Mukherjee, D. Downey, and S. Chakrabarti, "Vascular endothelial growth factor in diabetes induced early retinal abnormalities," Diabetes Research and Clinical Practice, vol. 65, no. 3, pp. 197-208, 2004.

[69] K. Musashi, J. Kiryu, K. Miyamoto, et al., "Thrombin inhibitor reduces leukocyte-endothelial cell interactions and vascular leakage after scatter laser photocoagulation," Investigative Ophthalmology \& Visual Science, vol. 46, no. 7, pp. 2561-2566, 2005.

[70] K. Muranaka, Y. Yanagi, Y. Tamaki, et al., "Effects of peroxisome proliferator-activated receptor $\gamma$ and its ligand on blood-retinal barrier in a streptozotocin-induced diabetic model," Investigative Ophthalmology \& Visual Science, vol. 47, no. 10, pp. 4547-4552, 2006.

[71] R. A. Kowluru, P. Koppolu, S. Chakrabarti, and S. Chen, "Diabetes-induced activation of nuclear transcriptional factor in the retina, and its inhibition by antioxidants," Free Radical Research, vol. 37, no. 11, pp. 1169-1180, 2003.

[72] L. Zheng, C. Szabó, and T. S. Kern, "Poly(ADP-ribose) polymerase is involved in the development of diabetic retinopathy via regulation of nuclear factor- $\kappa \mathrm{B}$," Diabetes, vol. 53 , no. 11 , pp. 2960-2967, 2004.

[73] G. Romeo, W.-H. Liu, V. Asnaghi, T. S. Kern, and M. Lorenzi, "Activation of nuclear factor- $\kappa \mathrm{B}$ induced by diabetes and high glucose regulates a proapoptotic program in retinal pericytes," Diabetes, vol. 51, no. 7, pp. 2241-2248, 2002.
[74] L. Zheng, S. J. Howell, D. A. Hatala, K. Huang, and T. S. Kern, "Salicylate-based anti-inflammatory drugs inhibit the early lesion of diabetic retinopathy," Diabetes, vol. 56, no. 2, pp. 337-345, 2007.

[75] R. A. Kowluru, J. Tang, and T. S. Kern, "Abnormalities of retinal metabolism in diabetes and experimental galactosemia: VII. Effect of long-term administration of antioxidants on the development of retinopathy," Diabetes, vol. 50, no. 8, pp. 1938-1942, 2001.

[76] A. M. Abu El-Asrar, S. Desmet, A. Meersschaert, L. Dralands, L. Missotten, and K. Geboes, "Expression of the inducible isoform of nitric oxide synthase in the retinas of human subjects with diabetes mellitus," American Journal of Ophthalmology, vol. 132, no. 4, pp. 551-556, 2001.

[77] R. A. Kowluru, R. L. Engerman, G. L. Case, and T. S. Kern, "Retinal glutamate in diabetes and effect of antioxidants," Neurochemistry International, vol. 38, no. 5, pp. 385-390, 2001.

[78] Y. Du, M. A. Smith, C. M. Miller, and T. S. Kern, "Diabetesinduced nitrative stress in the retina, and correction by aminoguanidine," Journal of Neurochemistry, vol. 80, no. 5, pp. 771-779, 2002.

[79] A. do Carmo, C. Lopes, M. Santos, R. Proença, J. CunhaVaz, and A. P. Carvalho, "Nitric oxide synthase activity and $\mathrm{L}$-arginine metabolism in the retinas from streptozotocininduced diabetic rats," General Pharmacology, vol. 30, no. 3, pp. 319-324, 1998.

[80] R. A. Kowluru, R. L. Engerman, and T. S. Kern, "Abnormalities of retinal metabolism in diabetes or experimental galactosemia VIII. Prevention by aminoguanidine," Current Eye Research, vol. 21, no. 4, pp. 814-819, 2000.

[81] R. A. Kowluru, "Retinal metabolic abnormalities in diabetic mouse: comparison with diabetic rat," Current Eye Research, vol. 24, no. 2, pp. 123-128, 2002.

[82] R. A. Kowluru, "Effect of reinstitution of good glycemic control on retinal oxidative stress and nitrative stress in diabetic rats," Diabetes, vol. 52, no. 3, pp. 818-823, 2003.

[83] A. M. Joussen, V. Poulaki, W. Qin, et al., "Retinal vascular endothelial growth factor induces intercellular adhesion molecule-1 and endothelial nitric oxide synthase expression and initiates early diabetic retinal leukocyte adhesion in vivo," American Journal of Pathology, vol. 160, no. 2, pp. 501509, 2002.

[84] J.-W. Park, S.-J. Park, S.-H. Park, et al., "Up-regulated expression of neuronal nitric oxide synthase in experimental diabetic retina," Neurobiology of Disease, vol. 21, no. 1, pp. 43-49, 2006.

[85] R. G. Tilton, G. Pugliese, L. S. LaRose, et al., "Discordant effects of the aldose reductase inhibitor, sorbinil, on vascular structure and function in chronically diabetic and galactosemic rats," Journal of Diabetic Complications, vol. 5, no. 4, pp. 230-237, 1991.

[86] J. A. Corbett, R. G. Tilton, K. Chang, et al., "Aminoguanidine, a novel inhibitor of nitric oxide formation, prevents diabetic vascular dysfunction," Diabetes, vol. 41, no. 4, pp. 552-556, 1992.

[87] K. Hasan, B.-J. Heesen, J. A. Corbett, et al., "Inhibition of nitric oxide formation by guanidines," European Journal of Pharmacology, vol. 249, no. 1-2, pp. 101-106, 1993.

[88] T. P. Misko, W. M. Moore, T. P. Kasten, et al., "Selective inhibition of the inducible nitric oxide synthase by aminoguanidine," European Journal of Pharmacology, vol. 233, no. 1, pp. 119-125, 1993. 
[89] T. S. Kern and R. L. Engerman, "Pharmacological inhibition of diabetic retinopathy: aminoguanidine and aspirin," Diabetes, vol. 50, no. 7, pp. 1636-1642, 2001.

[90] H.-P. Hammes, S. Martin, K. Federlin, K. Geisen, and M. Brownlee, "Aminoguanidine treatment inhibits the development of experimental diabetic retinopathy," Proceedings of the National Academy of Sciences of the United States of America, vol. 88, no. 24, pp. 11555-11558, 1991.

[91] H.-P. Hammes, M. Brownlee, D. Edelstein, M. Saleck, S. Martin, and K. Federlin, "Aminoguanidine inhibits the development of accelerated diabetic retinopathy in the spontaneous hypertensive rat," Diabetologia, vol. 37 , no. 1, pp. 3235, 1994.

[92] T. S. Kern, J. Tang, M. Mizutani, et al., "Response of capillary cell death to aminoguanidine predicts the development of retinopathy: comparison of diabetes and galactosemia," Investigative Ophthalmology \& Visual Science, vol. 41, no. 12, pp. 3972-3978, 2000.

[93] Y. Kobayashi and D. V. Maudsley, "Inhibition of histidine decarboxylase in rat stomach by aminoguanidine," British Journal of Pharmacology, vol. 43, no. 2, p. 426P, 1971.

[94] M. Brownlee, H. Vlassara, A. Kooney, P. Ulrich, and A. Cerami, "Aminoguanidine prevents diabetes-induced arterial wall protein cross-linking," Science, vol. 232, no. 4758, pp. 1629-1632, 1986.

[95] T. Rokkas, S. Vaja, G. M. Murphy, and R. H. Dowling, "Aminoguanidine blocks intestinal diamine oxidase (DAO) activity and enhances the intestinal adaptive response to resection in the rat," Digestion, vol. 46, supplement 2, pp. 447457, 1990.

[96] P. Ou and S. P. Wolff, "Aminoguanidine: a drug proposed for prophylaxis in diabetes inhibits catalase and generates hydrogen peroxide in vitro," Biochemical Pharmacology, vol. 46, no. 7, pp. 1139-1144, 1993.

[97] G. Jerums, T. Soulis-Liparota, S. Panagiotopoulos, and M. E. Cooper, In vivo Effects of Aminoguanidine, Royal Society of Chemistry, Cambridge, UK, 1994.

[98] J. R. Rumble, M. E. Cooper, T. Soulis, et al., "Aminoguanidine attenuates mesenteric vascular hypertrophy and TGF- $\beta$ 1 mRNA in diabetic rats," Diabetologia, vol. 39, suupplement 1, p. A70, 1996.

[99] Y. Al-Abed and R. Bucala, "Efficient scavenging of fatty acid oxidation products by aminoguanidine," Chemical Research in Toxicology, vol. 10, no. 8, pp. 875-879, 1997.

[100] P. H. Yu and D. M. Zuo, "Aminoguanidine inhibits semicarbazide-sensitive amine oxidase activity: implications for advanced glycation and diabetic complications," Diabetologia, vol. 40, no. 11, pp. 1243-1250, 1997.

[101] L. Zheng, Y. Du, C. Miller, et al., "Critical role of inducible nitric oxide synthase in degeneration of retinal capillaries in mice with streptozotocin-induced diabetes," Diabetologia, vol. 50, no. 9, pp. 1987-1996, 2007.

[102] N. Naveh-Floman, C. Weissman, and M. Belkin, "Arachidonic acid metabolism by retinas of rats with streptozotocininduced diabetes," Current Eye Research, vol. 3, no. 9, pp. 1135-1139, 1984.

[103] E. I. M. Johnson, M. E. Dunlop, and R. G. Larkins, "Increased vasodilatory prostaglandin production in the diabetic rat retinal vasculature," Current Eye Research, vol. 18, no. 2, pp. 79-82, 1999.

[104] S. P. Ayalasomayajula, A. C. Amrite, and U. B. Kompella, "Inhibition of cyclooxygenase-2, but not cyclooxygenase-1, reduces prostaglandin $\mathrm{E}_{2}$ secretion from diabetic rat retinas,"
European Journal of Pharmacology, vol. 498, no. 1-3, pp. 275278, 2004.

[105] S. Ishida, K. Yamashiro, T. Usui, et al., "Leukocytes mediate retinal vascular remodeling during development and vasoobliteration in disease," Nature Medicine, vol. 9, no. 6, pp. 781-788, 2003.

[106] A. J. Barber, D. A. Antonetti, T. S. Kern, et al., "The Ins2 $2^{\text {Akita }}$ mouse as a model of early retinal complications in diabetes," Investigative Ophthalmology \& Visual Science, vol. 46, no. 6, pp. 2210-2218, 2005.

[107] M. Lu, V. L. Perez, N. Ma, et al., "VEGF increases retinal vascular ICAM-1 expression in vivo," Investigative Ophthalmology \& Visual Science, vol. 40, no. 8, pp. 1808-1812, 1999.

[108] A. K. Hubbard and R. Rothlein, "Intercellular adhesion molecule-1 (ICAM-1) expression and cell signaling cascades," Free Radical Biology and Medicine, vol. 28, no. 9, pp. 1379-1386, 2000.

[109] W. Chen, D. B. Jump, M. B. Grant, W. J. Esselman, and J. V. Busik, "Dyslipidemia, but not hyperglycemia, induces inflammatory adhesion molecules in human retinal vascular endothelial cells," Investigative Ophthalmology \& Visual Science, vol. 44, no. 11, pp. 5016-5022, 2003.

[110] H. Sone, Y. Kawakami, Y. Okuda, et al., "Ocular vascular endothelial growth factor levels in diabetic rats are elevated before observable retinal proliferative changes," Diabetologia, vol. 40, no. 6, pp. 726-730, 1997.

[111] C. Gerhardinger, L. F. Brown, S. Roy, M. Mizutani, C. L. Zucker, and M. Lorenzi, "Expression of vascular endothelial growth factor in the human retina and in nonproliferative diabetic retinopathy," American Journal of Pathology, vol. 152, no. 6, pp. 1453-1462, 1998.

[112] Y. Segawa, Y. Shirao, S.-I. Yamagishi, et al., "Upregulation of retinal vascular endothelial growth factor mRNAs in spontaneously diabetic rats without ophthalmoscopic retinopathy. A possible participation of advanced glycation end products in the development of the early phase of diabetic retinopathy," Ophthalmic Research, vol. 30, no. 6, pp. 333-339, 1998.

[113] M. J. Tolentino, J. W. Miller, E. S. Gragoudas, et al., "Intravitreous injections of vascular endothelial growth factor produce retinal ischemia and microangiopathy in an adult primate," Ophthalmology, vol. 103, no. 11, pp. 1820-1828, 1996.

[114] M. J. Tolentino, D. S. McLeod, M. Taomoto, T. Otsuji, A. P. Adamis, and G. A. Lutty, "Pathologic features of vascular endothelial growth factor-induced retinopathy in the nonhuman primate," American Journal of Ophthalmology, vol. 133, no. 3, pp. 373-385, 2002.

[115] J. F. Arevalo, J. Fromow-Guerra, H. Quiroz-Mercado, et al., "Primary intravitreal bevacizumab (Avastin) for diabetic macular edema: results from the Pan-American Collaborative Retina Study Group at 6-month follow-up," Ophthalmology, vol. 114, no. 4, pp. 743-750, 2007.

[116] C. Starita, M. Patel, B. Katz, and A. P. Adamis, "Vascular endothelial growth factor and the potential therapeutic use of pegaptanib (macugen $囚$ ) in diabetic retinopathy," Developments in Ophthalmology, vol. 39, pp. 122-148, 2007.

[117] R. Jorge, R. A. Costa, D. Calucci, L. P. Cintra, and I. U. Scott, "Intravitreal bevacizumab (Avastin) for persistent new vessels in diabetic retinopathy (IBEPE study)," Retina, vol. 26, no. 9, pp. 1006-1013, 2006.

[118] E. W. M. Ng and A. P. Adamis, "Anti-VEGF aptamer (pegaptanib) therapy for ocular vascular diseases," Annals of the New York Academy of Sciences, vol. 1082, pp. 151-171, 2006. 
[119] R. L. Avery, J. Pearlman, D. J. Pieramici, et al., "Intravitreal bevacizumab (Avastin) in the treatment of proliferative diabetic retinopathy," Ophthalmology, vol. 113, no. 10, pp. 16951705.e6, 2006.

[120] J. O. Mason III, P. A. Nixon, and M. F. White, "Intravitreal Injection of bevacizumab (Avastin) as adjunctive treatment of proliferative diabetic retinopathy," American Journal of Ophthalmology, vol. 142, no. 4, pp. 685-688, 2006.

[121] A. P. Adamis, M. Altaweel, N. M. Bressler, et al., "Changes in retinal neovascularization after pegaptanib (Macugen) therapy in diabetic individuals," Ophthalmology, vol. 113, no. 1, pp. 23-28, 2006.

[122] R. A. Kowluru and S. Odenbach, "Role of interleukin-1 $\beta$ in the development of retinopathy in rats: effect of antioxidants," Investigative Ophthalmology \& Visual Science, vol. 45, no. 11, pp. 4161-4166, 2004.

[123] J. K. Krady, A. Basu, C. M. Allen, et al., "Minocycline reduces proinflammatory cytokine expression, microglial activation, and caspase- 3 activation in a rodent model of diabetic retinopathy," Diabetes, vol. 54, no. 5, pp. 1559-1565, 2005.

[124] S. Mohr, A. Xi, J. Tang, and T. S. Kern, "Caspase activation in retinas of diabetic and galactosemic mice and diabetic patients," Diabetes, vol. 51, no. 4, pp. 1172-1179, 2002.

[125] A. B. El-Remessy, M. Al-Shabrawey, Y. Khalifa, N.-T. Tsai, R. B. Caldwell, and G. I. Liou, "Neuroprotective and bloodretinal barrier-preserving effects of cannabidiol in experimental diabetes," American Journal of Pathology, vol. 168, no. 1, pp. 235-244, 2006.

[126] L. M. Le, V. Poulaki, K. Koizumi, S. Fauser, B. Kirchhof, and A. M. Joussen, "Reduced histopathological alterations in long-term diabetic TNF-R deficient mice," Investigative Ophthalmology \& Visual Science, vol. 44, supplement 2, p. 3894, 2003.

[127] C. Harada, A. Okumura, K. Namekata, et al., "Role of monocyte chemotactic protein-1 and nuclear factor $\kappa \mathrm{B}$ in the pathogenesis of proliferative diabetic retinopathy," Diabetes Research and Clinical Practice, vol. 74, no. 3, pp. 249-256, 2006.

[128] A. M. Joussen, V. Poulaki, N. Mitsiades, et al., "Suppression of Fas-FasL-induced endothelial cell apoptosis prevents diabetic blood-retinal barrier breakdown in a model of streptozotocin-induced diabetes," The FASEB Journal, vol. 17, no. 1, pp. 76-78, 2003.

[129] J. Zhang, C. Gerhardinger, and M. Lorenzi, "Early complement activation and decreased levels of glycosylphosphatidylinositol-anchored complement inhibitors in human and experimental diabetic retinopathy," Diabetes, vol. 51, no. 12, pp. 3499-3504, 2002.

[130] J. Acosta, J. Hettinga, R. Flückiger, et al., "Molecular basis for a link between complement and the vascular complications of diabetes," Proceedings of the National Academy of Sciences of the United States of America, vol. 97, no. 10, pp. 5450-5455, 2000.

[131] C. S. Davies, C. L. Harris, and B. P. Morgan, "Glycation of CD59 impairs complement regulation on erythrocytes from diabetic subjects," Immunology, vol. 114, no. 2, pp. 280-286, 2005.

[132] X. Qin, A. Goldfine, N. Krumrei, et al., "Glycation inactivation of the complement regulatory protein CD59: a possible role in the pathogenesis of the vascular complications of human diabetes," Diabetes, vol. 53, no. 10, pp. 2653-2661, 2004.
[133] J. R. Gamble, J. Drew, and L. Trezise, "Angiopoietin-1 is an antipermeability and anti-inflammatory agent in vitro and targets cell junctions," Circulation Research, vol. 87, no. 7, pp. 603-607, 2000.

[134] S. Chakrabarti and A. A. F. Sima, "Effect of aldose reductase inhibition and insulin treatment on retinal capillary basement membrane thickening in BB rats," Diabetes, vol. 38, no. 9, pp. 1181-1186, 1989.

[135] R. A. Kowluru and S. Odenbach, "Effect of long-term administration of $\alpha$-lipoic acid on retinal capillary cell death and the development of retinopathy in diabetic rats," Diabetes, vol. 53, no. 12, pp. 3233-3238, 2004.

[136] H. P. Hammes, A. Bartmann, L. Engel, and P. Wülfroth, "Antioxidant treatment of experimental diabetic retinopathy in rats with nicanartine," Diabetologia, vol. 40, no. 6, pp. 629634, 1997.

[137] H.-P. Hammes, X. Du, D. Edelstein, et al., "Benfotiamine blocks three major pathways of hyperglycemic damage and prevents experimental diabetic retinopathy," Nature Medicine, vol. 9, no. 3, pp. 294-299, 2003.

[138] A. Bierhaus, D. M. Stern, and P. P. Nawroth, "RAGE in inflammation: a new therapeutic target?" Current Opinion in Investigational Drugs, vol. 7, no. 11, pp. 985-991, 2006.

[139] A. Goldin, J. A. Beckman, A. M. Schmidt, and M. A. Creager, "Advanced glycation end products: sparking the development of diabetic vascular injury," Circulation, vol. 114, no. 6, pp. 597-605, 2006.

[140] M. Alves, V. C. Calegari, D. A. Cunha, M. J. A. Saad, L. A. Velloso, and E. M. Rocha, "Increased expression of advanced glycation end-products and their receptor, and activation of nuclear factor $\kappa \mathrm{B}$ in lacrimal glands of diabetic rats," Diabetologia, vol. 48, no. 12, pp. 2675-2681, 2005.

[141] L. Gu, S. Hagiwara, Q. Fan, et al., "Role of receptor for advanced glycation end-products and signalling events in advanced glycation end-product-induced monocyte chemoattractant protein-1 expression in differentiated mouse podocytes," Nephrology Dialysis Transplantation, vol. 21, no. 2, pp. 299-313, 2006.

[142] K.-M. Haslbeck, A. Bierhaus, S. Erwin, et al., "Receptor for advanced glycation endproduct (RAGE)-mediated nuclear factor- $\kappa \mathrm{B}$ activation in vasculitic neuropathy," Muscle \& Nerve, vol. 29, no. 6, pp. 853-860, 2004.

[143] J. C. Mamputu and G. Renier, "Advanced glycation endproducts increase monocyte adhesion to retinal endothelial cells through vascular endothelial growth factor-induced ICAM-1 expression: inhibitory effect of antioxidants," Journal of Leukocyte Biology, vol. 75, no. 6, pp. 1062-1069, 2004.

[144] R. Tammali, K. V. Ramana, S. S. Singhal, S. Awasthi, and S. K. Srivastava, "Aldose reductase regulates growth factorinduced cyclooxygenase- 2 expression and prostaglandin $\mathrm{E}_{2}$ production in human colon cancer cells," Cancer Research, vol. 66, no. 19, pp. 9705-9713, 2006.

[145] K. V. Ramana, B. Friedrich, S. Srivastava, A. Bhatnagar, and S. K. Srivastava, "Activation of nulcear factor- $\kappa \mathrm{B}$ by hyperglycemia in vascular smooth muscle cells is regulated by aldose reductase," Diabetes, vol. 53, no. 11, pp. 2910-2920, 2004.

[146] K. V. Ramana, A. Bhatnagar, and S. K. Srivastava, "Inhibition of aldose reductase attenuates TNF- $\alpha$-induced expression of adhesion molecules in endothelial cells," The FASEB Journal, vol. 18, no. 11, pp. 1209-1218, 2004. 
[147] W. Sun, C. Gerhardinger, Z. Dagher, T. Hoehn, and M. Lorenzi, "Aspirin at low-intermediate concentrations protects retinal vessels in experimental diabetic retinopathy through non-platelet-mediated effects," Diabetes, vol. 54, no. 12, pp. 3418-3426, 2005.

[148] L. Zheng and T. S. Kern, "Non-steroidal anti-inflammatory drugs (NSAIDs) inhibit development of early stages of diabetic retinopathy," Diabetes, 2005, Abstract 929-P.

[149] J. J. Steinle, "Sympathetic neurotransmission modulates expression of inflammatory markers in the rat retina," Experimental Eye Research, vol. 84, no. 1, pp. 118-125, 2007.

[150] T. Abiko, A. Abiko, A. C. Clermont, et al., "Characterization of retinal leukostasis and hemodynamics in insulin resistance and diabetes: role of oxidants and protein kinase- $\mathrm{C}$ activation," Diabetes, vol. 52, no. 3, pp. 829-837, 2003.

[151] E. A. Felinski and D. A. Antonetti, "Glucocorticoid regulation of endothelial cell tight junction gene expression: novel treatments for diabetic retinopathy," Current Eye Research, vol. 30, no. 11, pp. 949-957, 2005.

[152] A. K. Dubey, "Intravitreal injection of triamcinolone acetonide for diabetic macular edema: principles and practice," Indian Journal of Ophthalmology, vol. 54, no. 4, pp. 290-291, 2006.

[153] A. Ramezani, H. Ahmadieh, and H. Tabatabaei, "Intravitreal triamcinolone reinjection for refractory diabetic macular edema," Korean Journal of Ophthalmology, vol. 20, no. 3, pp. 156-161, 2006.

[154] N. Miyamoto, D. Iossifov, F. Metge, and F. Behar-Cohen, "Early effects of intravitreal triamcinolone on macular edema: mechanistic implication," Ophthalmology, vol. 113, no. 11, pp. 2048-2053, 2006.

[155] J. B. Jonas, B. A. Kamppeter, B. Harder, U. Vossmerbaeumer, G. Sauder, and U. H. M. Spandau, "Intravitreal triamcinolone acetonide for diabetic macular edema: a prospective, randomized study," Journal of Ocular Pharmacology and Therapeutics, vol. 22, no. 3, pp. 200-207, 2006.

[156] J. B. Jonas, "Intravitreal triamcinolone acetonide for diabetic retinopathy," Developments in Ophthalmology, vol. 39, pp. 96-110, 2007.

[157] R. A. Greenwald and L. M. Golub, "Biologic properties of non-antibiotic, chemically modified tetracyclines (CMTs): as structured, annotated bibliography," Current Medicinal Chemistry, vol. 8, no. 3, pp. 237-242, 2001.

[158] A. R. Amin, M. G. Attur, G. D. Thakker, et al., "A novel mechanism of action of tetracyclines: effects on nitric oxide synthases," Proceedings of the National Academy of Sciences of the United States of America, vol. 93, no. 24, pp. 14014-14019, 1996.

[159] J. Yrjänheikki, T. Tikka, R. Keinänen, G. Goldsteins, P. H. Chan, and J. Koistinaho, "A tetracycline derivative, minocycline, reduces inflammation and protects against focal cerebral ischemia with a wide therapeutic window," Proceedings of the National Academy of Sciences of the United States of America, vol. 96, no. 23, pp. 13496-13500, 1999.

[160] S. Zhu, I. G. Stavrovskaya, M. Drozda, et al., "Minocycline inhibits cytochrome c release and delays progression of amyotrophic lateral sclerosis in mice," Nature, vol. 417, no. 6884, pp. 74-78, 2002.

[161] C. X. Wang, T. Yang, and A. Shuaib, "Effects of minocycline alone and in combination with mild hypothermia in embolic stroke," Brain Research, vol. 963, no. 1-2, pp. 327-329, 2003.
[162] R. Pi, W. Li, N. T. K. Lee, et al., "Minocycline prevents glutamate-induced apoptosis of cerebellar granule neurons by differential regulation of p38 and Akt pathways," Journal of Neurochemistry, vol. 91, no. 5, pp. 1219-1230, 2004.

[163] R. M. Bonelli, A. K. Hödl, P. Hofmann, and H.-P. Kapfhammer, "Neuroprotection in Huntington's disease: a 2-year study on minocycline," International Clinical Psychopharmacology, vol. 19, no. 6, pp. 337-342, 2004.

[164] P. A. LeWitt, "Clinical trials of neuroprotection for Parkinson's disease," Neurology, vol. 63, no. 7, supplement 2, pp. S23-S31, 2004.

[165] D. C. Baptiste, A. T. E. Hartwick, C. A. B. Jollimore, W. H. Baldridge, G. M. Seigel, and M. E. M. Kelly, "An investigation of the neuroprotective effects of tetracycline derivatives in experimental models of retinal cell death," Molecular Pharmacology, vol. 66, no. 5, pp. 1113-1122, 2004.

[166] N. Reynolds, "Revisiting safety of minocycline as neuroprotection in Huntington's disease," Movement Disorders, vol. 22, no. 2, p. 292, 2007.

[167] H. F. Elewa, R. Hilali, D. C. Hess, L. S. Machado, and S. C. Fagan, "Minocycline for short-term neuroprotection," Pharmacotherapy, vol. 26, no. 4, pp. 515-521, 2006.

[168] A. Y. Lai and K. G. Todd, "Hypoxia-activated microglial mediators of neuronal survival are differentially regulated by tetracyclines," GLIA, vol. 53, no. 8, pp. 809-816, 2006.

[169] J. Neumann, M. Gunzer, H. O. Gutzeit, O. Ullrich, K. G. Reymann, and K. Dinkel, "Microglia provide neuroprotection after ischemia," The FASEB Journal, vol. 20, no. 6, pp. 714716, 2006.

[170] M. Chen, V. O. Ona, M. Li, et al., "Minocycline inhibits caspase- 1 and caspase-3 expression and delays mortality in a transgenic mouse model of Huntington disease," Nature Medicine, vol. 6, no. 7, pp. 797-801, 2000.

[171] M. Domercq and C. Matute, "Neuroprotection by tetracyclines," Trends in Pharmacological Sciences, vol. 25, no. 12, pp. 609-612, 2004.

[172] L. W. Ai, A. C. H. Yu, T. L. Lau, et al., "Minocycline inhibits LPS-induced retinal microglia activation," Neurochemistry International, vol. 47, no. 1-2, pp. 152-158, 2005.

[173] K. Kojima, H. Matsubara, T. Harada, et al., "Effects of aldose reductase inhibitor on retinal microangiopathy in streptozotocin-diabetic rats," Japanese Journal of Ophthalmology, vol. 29, no. 1, pp. 99-109, 1985.

[174] W. Sun, P. J. Oates, J. B. Coutcher, C. Gerhardinger, and M. Lorenzi, "A selective aldose reductase inhibitor of a new structural class prevents or reverses early retinal abnormalities in experimental diabetic retinopathy," Diabetes, vol. 55, no. 10, pp. 2757-2762, 2006.

[175] Sorbinil Retinopathy Trial Research Group, "A randomized trial of sorbinil, an aldose reductase inhibitor, in diabetic retinopathy," Archives of Ophthalmology, vol. 108, no. 9, pp. 1234-1244, 1990.

[176] C. Arauz-Pacheco, L. C. Ramirez, L. Pruneda, G. E. Sanborn, J. Rosenstock, and P. Raskin, "The effect of the aldose reductase inhibitor, ponalrestat, on the progression of diabetic retinopathy," Journal of Diabetes and Its Complications, vol. 6, no. 2, pp. 131-137, 1992.

[177] K. V. Ramana, M. S. Willis, M. D. White, et al., "Endotoxininduced cardiomyopathy and systemic inflammation in mice is prevented by aldose reductase inhibition," Circulation, vol. 114, no. 17, pp. 1838-1846, 2006. 
[178] C. Li, Y. Xu, D. Jiang, et al., "The expression of HIF-1 in the early diabetic NOD mice," Yan Ke Xue Bao, vol. 22, no. 2, pp. 107-111, 2006.

[179] T. Yuuki, T. Kanda, Y. Kimura, et al., "Inflammatory cytokines in vitreous fluid and serum of patients with diabetic vitreoretinopathy," Journal of Diabetes and Its Complications, vol. 15 , no. 5, pp. 257-259, 2001.

[180] M. Myśliwiec, K. Zorena, A. Balcerska, J. Myśliwska, P. Lipowski, and K. Raczyńska, "The activity of $N$-acetyl-betaD-glucosaminidase and tumor necrosis factor-alpha at early stage of diabetic retinopathy development in type 1 diabetes mellitus children," Clinical Biochemistry, vol. 39, no. 8, pp. 851-856, 2006.

[181] N. Demircan, B. G. Safran, M. Soylu, A. A. Ozcan, and S. Sizmaz, "Determination of vitreous interleukin-1(IL-1) and tumour necrosis factor (TNF) levels in proliferative diabetic retinopathy," Eye, vol. 20, no. 12, pp. 1366-1369, 2006.

[182] J.-M. González-Clemente, D. Mauricio, C. Richart, et al., "Diabetic neuropathy is associated with activation of the TNF- $\alpha$ system in subjects with type 1 diabetes mellitus," Clinical Endocrinology, vol. 63, no. 5, pp. 525-529, 2005.

[183] S. Doganay, C. Evereklioglu, H. Er, et al., "Comparison of serum NO, TNF- $\alpha$, IL- $1 \beta$, sIL-2R, IL-6 and IL- 8 levels with grades of retinopathy in patients with diabetes mellitus," Eye, vol. 16, no. 2, pp. 163-170, 2002.

[184] G. Zoppini, G. Faccini, M. Muggeo, L. Zenari, G. Falezza, and G. Targher, "Elevated plasma levels of soluble receptors of TNF- $\alpha$ and their association with smoking and microvascular complications in young adults with type I diabetes," Journal of Clinical Endocrinology and Metabolism, vol. 86, no. 8, pp. 3805-3808, 2001.

[185] J. Tang, S. Mohr, Y.-P. Du, and T. S. Kern, "Non-uniform distribution of lesions and biochemical abnormalities within the retina of diabetic humans," Current Eye Research, vol. 27, no. 1, pp. 7-13, 2003.

[186] C. Baudoin, P. Passa, P. Sharp, and E. Kohner, "Effect of aspirin alone and aspirin plus dipyridamole in early diabetic retinopathy: a multicenter randomized controlled clinical trial," Diabetes, vol. 38, no. 4, pp. 491-498, 1989.

[187] Early Treatment Diabetic Retinopathy Research Group, "Effects of aspirin treatment on diabetic retinopathy," Ophthalmol, vol. 98, supplement 5, pp. 757-765, 1991.

\section{AUTHOR CONTACT INFORMATION}

Timothy S. Kern: Department of Medicine, Case Western Reserve University, Cleveland, OH 44106-5029, USA; Department of Ophthalmology and Visual Sciences, Case Western Reserve University, Cleveland, OH 44106-5068, USA; Cleveland VA Medical Center, 10701 East Boulevard, Cleveland, OH 44106, USA; tsk@case.edu 


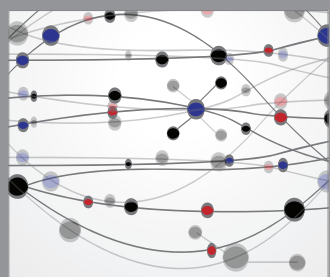

The Scientific World Journal
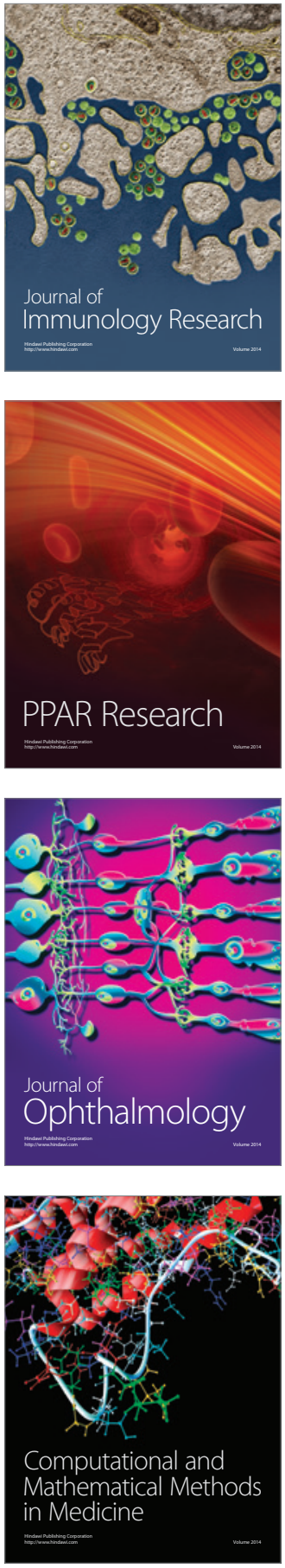

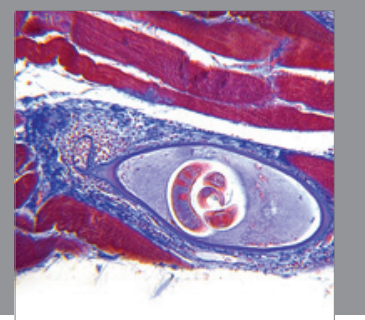

Gastroenterology

Research and Practice
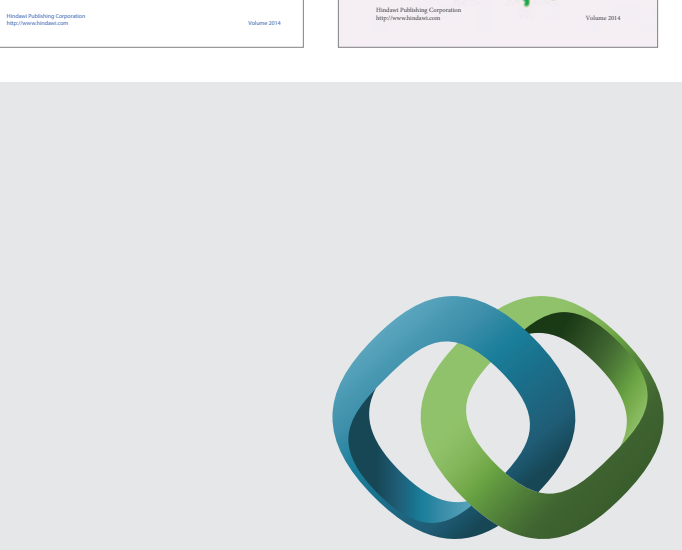

\section{Hindawi}

Submit your manuscripts at

http://www.hindawi.com
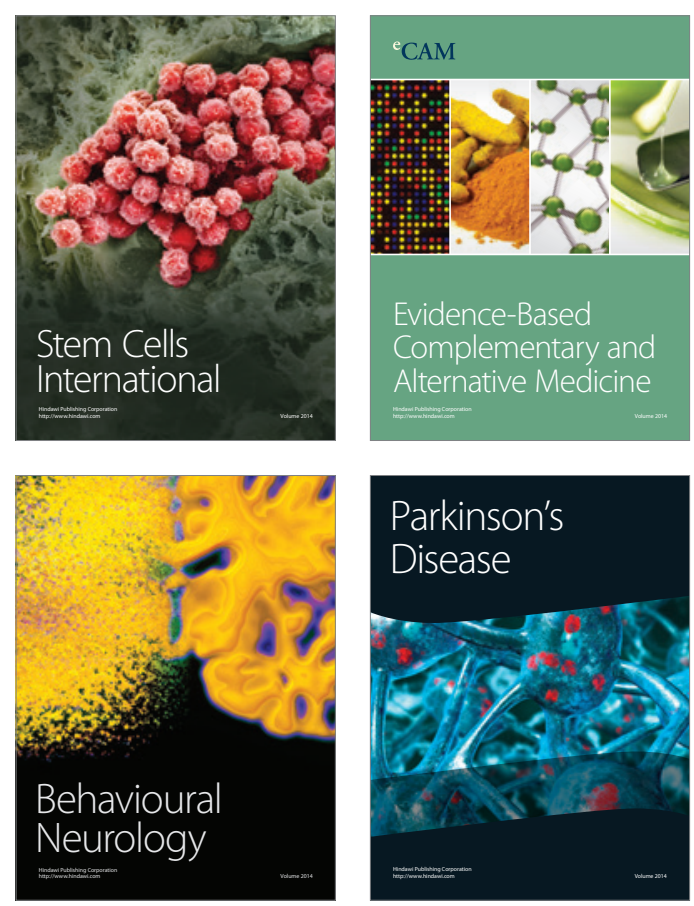

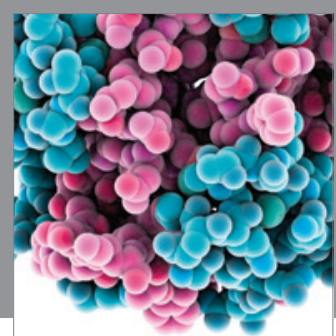

Journal of
Diabetes Research

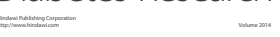

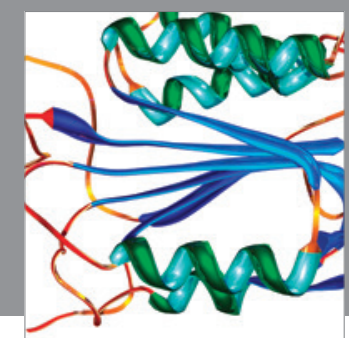

Disease Markers
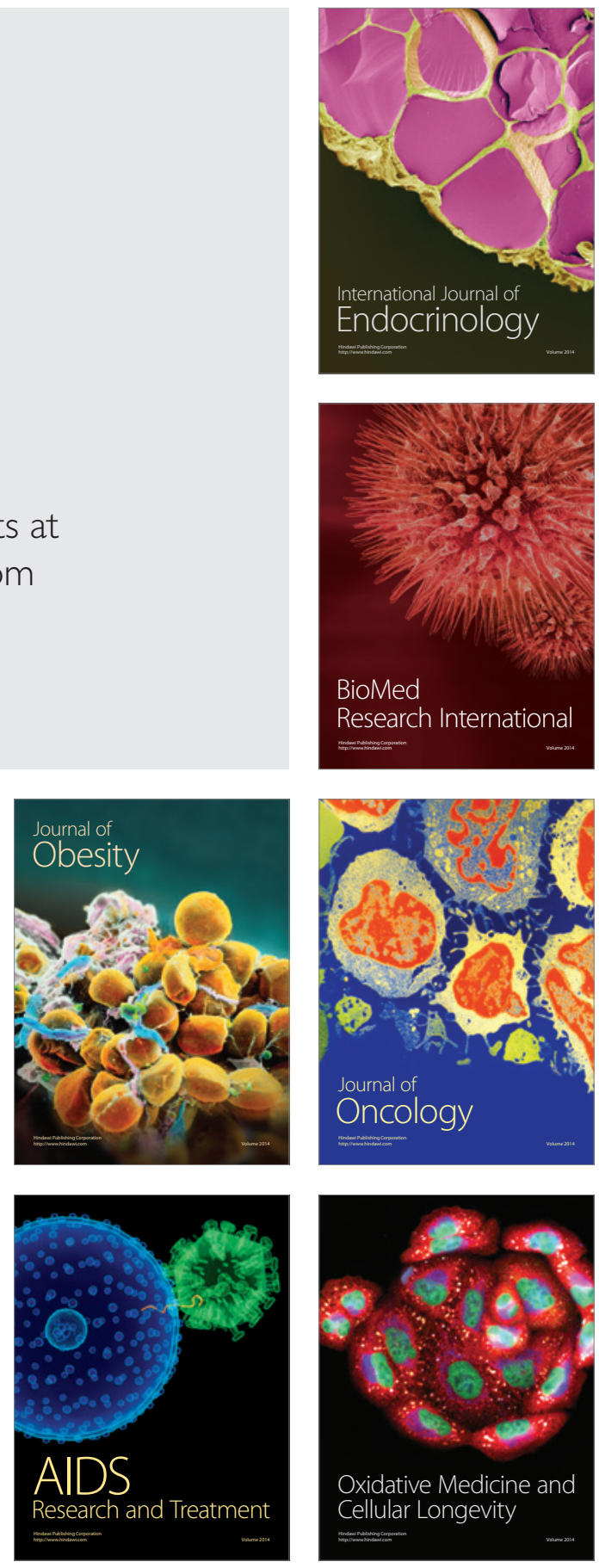